\title{
BIOLOGICALLY-INSPIRED INNOVATION IN LARGE COMPANIES: A PATH FOR CORPORATE PARTICIPATION IN BIOPHYSICAL SYSTEMS?
}

\author{
T.L. MEAD \\ Centre for Innovation and Service Research, School of Business, University of Exeter, UK
}

\begin{abstract}
The use of Biologically-Inspired Design (BID) has become increasingly prominent as an innovation tool for sustainability in large corporations. This research, from the perspective of innovation management and organizational development, explores the use of BID as a tool for corporate sustainability at multiple levels and reflects on the implications for corporate sustainability agendas. The review of the literature analyses the history of BID in a broad sense, both with and without sustainability objectives, and disambiguates several aspects of the field that have been largely overlooked in the popular media. Many corporate managers are utilizing the methods and tools of BID with little understanding of how they may or may not connect to corporate sustainability objectives of the organization. This research aims to bring this to light and create a much-needed critical dialogue around the use of BID for sustainability-oriented innovation (SOI). A four-tiered model is used to frame the use of BID in this setting and existing case studies are used to test the model. Research outcomes include creating a framework for understanding how BID can be used to inform innovative solutions within the product, process, organizational and systems-levels by embedding sustainability criteria at each level using various biological models. The aim of this research is not to simply deconstruct BID, but rather to create a dialogue amongst sustainability practitioners, corporate professionals and academics that increases the robustness of the tool for use in achieving sustainability goals and objectives.

Keywords: Biomimicry, Biologically-Inspired Design, Biomimetics, Corporate Sustainability, SustainabilityOriented Innovation.
\end{abstract}

\section{INTRODUCTION}

"One has to make up his mind whether he wants simple answers to his questions—or useful ones... you cannot have both." J.A. Schumpeter

The use of Biologically-Inspired Design (BID) is clearly not new. Scholars, designers and inventors as early as Leonardo Da Vinci have been seeking inspiration from nature for design innovation [1]. What are new are the broad reaching effects of biomimetic principles across numerous disciplines simultaneously, as is evident in this publication and others. BIDs can be seen amongst research labs, entrepreneurs and corporate $R \& D$ departments around the globe [2-5]. BID related patents are among the fastest growing forms of innovations registered between 1985-2005 [6]. The concept is prolific enough across sectors that an economic index, the Da Vinci Index, was recently created to monitor and report on its activity [7]. Just as traditional models of innovation indicate [8-11], biomimetic innovations happen at multiple levels [12]. They can be found in form, product, process, system, organization and management innovations in applications as diverse as the individuals developing the ideas. There is a common (and questionably erroneous) view that 'design strategies' found in non-human natural systems are different from and superior to human capabilities [13-15]. BIDs are changing the way that humans view the natural world from merely a resource base to a source of design insights [12]. There is now a common belief that humans will become more sustainable using BID as a catalyst for innovation in a range of industries $[12,13,16]$.

And paradoxically, as these concepts move inquisitively along through the processes of innovation, design, research and practice, there continues to be an urgency amongst human societies to address issues of environmental peril that have resulted from the legacy of this very same innovation

(C) 2014 WIT Press, www.witpress.com

ISSN: 1755-7437 (paper format), ISSN: 1755-7445 (online), http://journals.witpress.com

DOI: 10.2495/DNE-V9-N3-216-229 
and design $[17,18]$. It has been well-documented that the human species is reaching the limits of its ecologically-viable niche in the biosphere [19-21]. With these limits in mind, it begs the questions: 'To what ends are we innovating? What are the goals of innovation? If sustainability is the goal, how do we know if we are contributing to sustainable development? Is biologically-inspired innovation contributing to this goal?'

\section{THE STATE OF CORPORATE SUSTAINABILITY}

Numerous tools and strategies have been developed within the private sector to move towards the goal of sustainable development in the last 30 years. Platforms such as the Triple Bottom Line, the Global Reporting Initiative, UN Global Compact and ISO 140001 have emerged as tools to help companies manage and report on their social, environmental and economic impacts [22-25]. There are also numerous systems of metrics that measure sustainability of the city, household, product and others [26-29]. While these efforts to quantify and monitor sustainability, environmental impacts, and consumption are noble attempts to guide us toward sustainable development, they unfortunately do not provide any guidance regarding the limits of human growth in a biophysical sense or give policy makers reliable data upon which to base decisions [26,30,31]. Nevertheless, these tools have been successful in creating greater awareness amongst corporations, their shareholders and their stakeholders regarding the impacts of business in society and the biosphere. These tools have also changed the tone of business rhetoric from simple remediation of environmental harm to more active participation as global players in sustainable development. The language on corporate relationships to the environment includes a wide array of terms - such as 'greening', 'environmental', 'eco-innovation' and others - that generally have little to do with any social implications of the product life-cycle or manufacturing processes, but rather focus on reducing resource use and increasing product efficiency. An increasingly used term, 'sustainability-oriented innovation' (SOI) focuses on a broader view of corporate relationships to nature and society and has become a key conversation in corporate strategy $[9,32]$. Despite this progress, there has been a great deal of scepticism about the effectiveness of these and similar efforts. Today, human patterns of consumption and production are still using resources and creating pollution at an unsustainable pace [21,26,31]. 'We simply do not know to what extent corporate greening actually contributes to ecological sustainability or whether it does at all' [33].

It is with this situation in mind that it becomes important to explore the relationship of biologically-inspired design and innovation in the overall agenda of sustainability in the private sector. This analysis aims to highlight some of the key misunderstandings of the use of biologically-inspired innovation in large companies as a tool and process for sustainability. The enormous promise of BID portrayed in the popular media leaves one to wonder if biologically-inspired innovation processes do indeed produce sustainability-oriented results.

\section{DISAMBIGUATION OF TERMS}

The human species has evolved outstanding capabilities in its use of language and technology to describe, manipulate and emulate design principles in nature, such as those principles described by constructal law and ecological theory [34]. While the concepts of learning from nature for human design can be traced back to pre-history, BID has only been gaining distinction as a field of study since the 1950s and 1960s. The historical use of terms has been well-documented in this publication and others [35-37], is summarized in the table below. There are, however, a few points of departure not previously described that are worth mentioning. 
Table 1: Historical timeline of the emergence of BID concepts

\begin{tabular}{|c|c|c|c|c|}
\hline Term (Year) & $\begin{array}{l}\text { Attributed } \\
\text { To }\end{array}$ & $\begin{array}{l}\text { Training of } \\
\text { Originator }\end{array}$ & Definition (where available) & $\begin{array}{l}\text { Connection } \\
\text { to Sustain- } \\
\text { ability }\end{array}$ \\
\hline $\begin{array}{l}\text { Bionics } \\
\text { (1958) }\end{array}$ & $\begin{array}{l}\text { Jack E. } \\
\text { Steele }\end{array}$ & $\begin{array}{l}\text { Medical } \\
\text { Doctor }\end{array}$ & $\begin{array}{l}\text { 'The science of systems which have some } \\
\text { function copied from nature, or which repre- } \\
\text { sent characteristics of natural systems or their } \\
\text { analogues.' [42] }\end{array}$ & No \\
\hline $\begin{array}{l}\text { Biomimetics } \\
\text { (1969) }\end{array}$ & $\begin{array}{l}\text { Otto } \\
\text { Schmidt }\end{array}$ & $\begin{array}{l}\text { Engineer/ } \\
\text { Biophysicist }\end{array}$ & $\begin{array}{l}\text { 'The study of the formation, structure, or } \\
\text { function of biologically produced substances } \\
\text { and materials (as enzymes or silk) and bio- } \\
\text { logical mechanisms and processes (as protein } \\
\text { synthesis or photosynthesis) especially for the } \\
\text { purpose of synthesizing similar products by } \\
\text { artificial mechanisms which mimic natural } \\
\text { ones.' [43] }\end{array}$ & No \\
\hline $\begin{array}{l}\text { Design with } \\
\text { Nature } \\
(1969)\end{array}$ & $\begin{array}{l}\text { Ian } \\
\text { McHarg }\end{array}$ & $\begin{array}{l}\text { Landscape } \\
\text { Architect }\end{array}$ & $\begin{array}{l}\text { 'The ecological view requires that we look } \\
\text { upon the world, listen and learn.' [39] }\end{array}$ & Yes \\
\hline $\begin{array}{l}\text { Ecological } \\
\text { Design (1970s) }\end{array}$ & John Todd & Biologist & $\begin{array}{l}\text { Defined by a set of } 9 \text { principles in the book } \\
\text { 'From Eco-Cities to Living Machines: Prin- } \\
\text { ciples of Ecological Design.' [37] }\end{array}$ & Yes \\
\hline $\begin{array}{l}\text { Biomimicry } \\
(1997)\end{array}$ & $\begin{array}{l}\text { Janine } \\
\text { Benyus }\end{array}$ & Biologist & $\begin{array}{l}\text { 'An innovation method that seeks sustainable } \\
\text { solutions to human challenges by emulating } \\
\text { nature's time-tested phenomena, patterns and } \\
\text { principles. The goal is to create well-adapted } \\
\text { products, processes, designs and policies } \\
\text { by mimicking how living organisms have } \\
\text { survived and thrived over the } 3.8 \text { billion years } \\
\text { life has existed on Earth.' [44] }\end{array}$ & Yes \\
\hline $\begin{array}{l}\text { Ecomimicry } \\
(2007)\end{array}$ & $\begin{array}{l}\text { Alan } \\
\text { Marshall }\end{array}$ & $\begin{array}{l}\text { Social } \\
\text { Scientist }\end{array}$ & $\begin{array}{l}\text { 'Ecomimicry is the practice of designing so- } \\
\text { cially responsive and environmental responsi- } \\
\text { ble technologies for a particular locale based } \\
\text { upon the characteristics of animals, plants } \\
\text { and ecosystems of that locale.' [41] }\end{array}$ & Yes \\
\hline $\begin{array}{l}\text { Nature- } \\
\text { Inspired Design } \\
\text { Strategies } \\
(2010)\end{array}$ & $\begin{array}{l}\text { Pauw, } \\
\text { et al. }\end{array}$ & $\begin{array}{l}\text { Industrial } \\
\text { Designer }\end{array}$ & $\begin{array}{l}\text { 'Nature-inspired design strategies are design } \\
\text { strategies that base a significant proportion of } \\
\text { their theory on 'learning from nature' and re- } \\
\text { gard nature as the paradigm of sustainability.' } \\
\text { E.g., biomimicry, cradle-to-cradle and natural } \\
\text { capitalism. [3] }\end{array}$ & Yes \\
\hline $\begin{array}{l}\text { Biologically } \\
\text { Informed } \\
\text { Discipline } \\
\text { (2014) }\end{array}$ & $\begin{array}{l}\text { Alena } \\
\text { Iouguina }\end{array}$ & $\begin{array}{l}\text { Industrial } \\
\text { Designer }\end{array}$ & $\begin{array}{l}\text { 'The informed interpretation of biological } \\
\text { research in order to address human challenges } \\
\text { for the purpose of innovation that may or may } \\
\text { not result in sustainable solutions.' [37] }\end{array}$ & Yes and No \\
\hline
\end{tabular}


Some key components of the modern BID dialogue that are often overlooked have their origins in the built environment. Buckminster Fuller introduced some of the early thinking in architecture [38], followed by Ian McHarg in landscape architecture [39] and John Todd in the design of living machines [37]. Iouguina, et al. highlighted many of the key distinctions amongst terms and the users of terms elsewhere in these proceedings [37]. As a point of clarification from that piece, the term 'biomimicry' first appeared in the literature in 1982 in the context of dentistry [40], but was later popularized in the context of SOIs in 1997 by Janine Benyus. It was this connection of BID to sustainable development in Benyus's release of Biomimicry: Innovation Inspired by Nature, which started a flurry of activity in North America. This compilation of case studies reconnected the innovations and technologies of the human species to the biosphere and repositioned humans as one of the many species learning to adapt to the planet. This framing changed the dialogue in a subtle but significant way. From Benyus's perspective, the processes of innovation are closely linked with the processes of evolution. This positioning was a critical component in connecting inspiration from nature to the conservation of nature that led to the landslide of popular literature on the subject since 1997 [12].

In 2007, Marshall wrote of the term ecomimicry, which incorporated place-specific and social aspects of sustainability as an alternative to biomimicry. While understandable given the muddled history of terms, his erroneous perception was that biomimicry was limited to technological applications of biological strategies out of ecological context and was attempting to fill a non-existent gap in the thinking [41]. Since then, Pauw et al. created a definition that encompasses the terms biomimicry, cradle-to-cradle and natural capitalism in a framework of 'Nature-Inspired Design Strategies' to differentiate sustainability-oriented BID from approaches without ethical considerations [3].

While practitioners use the many terms interchangeably, there are effectively two schools of thought that divide the BID innovation space that are not consistently associated with the particular terms. The first is the use of biological models to inform design solutions because of the unique and outstanding physical properties of biological system and without explicit considerations for the ethical implications of the outcomes. The second is the use of biological models to inform design solutions to solve challenges of sustainability and human adaptability. And while this slight variation may seem inconsequential, there are significant differences in the intentions, goals and outcomes of such approaches that can be misleading and confusing for those engaging in BID who are new to the concepts of sustainability. It could be argued that this distinction is more important than the terms themselves.

As is evident from previous research, there is no common definition for these terms and yet, they are frequently used interchangeably. These various disciplines are often clustered together and consequently, the validity of BID as a tool for SOI is called into question $[36,45,46]$, and rightly so. A paper in the journal Bioinspiration \& Biomimetics entitled 'The State of the Art in Biomimetics' makes no mention of the words sustainability or environment [47]. This type of omission in the literature is not an anomaly. A search of the journal Bioinspiration \& Biomimetics from its start in 2006 until Volume 9, Number 1 in 2014 returned only seven instances of the term 'sustainability', suggesting that this body of research in BID is greatly decontextualized from biophysical realities and social ethics. There are numerous cultural interpretations of biological processes that are completely absent of notions of sustainability, and in some instances to the opposite extreme, have been used for destructive purposes $[45,48]$. Indeed, the United States Department of Defence is one of the largest funders of biomimetic research [36,45]. BID has been called a 'technocentric' approach which is effective as a human-focused tool for innovation, but lacks an 'ecocentric' approach that would define nature as having intrinsic value and connects humans to natural systems. Marshall and Lozeva say: 'It is also noteworthy that the prime funders of large-scale biomimicry research are 
tending to be the defence industry along with various large corporations' (Emphasis added) [36]. The authors seem to be, somewhat naively, pairing the defence industry with large corporations as if the two were ethically equivocal. However, according to publications such as National Geographic, Fast Company, Bloomberg News, The Guardian and others [49-52], many corporations are now using BID for SOI.

Although there has been no documentation of clearly described strategies, methods and design principles of BID in commercial product development of sustainable products [3], there are welldocumented case studies of sustainability-oriented BID in corporate settings $[4,12,53,54]$. The lack of documentation of BID strategies, etc. in corporate settings is likely due to the non-disclosure of intellectual property more so than a lack of strategies for BID design in the private sector. For example, the consulting group within Biomimicry 3.8 has a corporate client list with major brands including Boeing, Nike, GE, Proctor and Gamble, Kraft and others, suggesting that these companies are engaging in BID for SOI [44].

While there are extremes regarding the issue of sustainable vs. destructive BID, another perspective emerging in this space is one of a more cautious optimism and middle ground. Volstad and Boks explore the benefits and challenges of using BID from the perspective of industrial designers and are cautious about the use of the tool as a panacea solution to all human-created problems in design [55]. Pauw et al. note that there is little to no evidence that nature-inspired design produces more sustainable results within product design, however, sustainability-oriented product design does produce better-suited designs than having no goals whatsoever and BID is a tool well-suited for this purpose [3]. Is this due to a lack of connection of BID to sustainability in actuality or merely a lack of research attempting to address the subject? The qualification of sustainability is, after all, one of the most difficult challenges of our time.

As is evident, the use of BID for sustainable development is a highly contested issue with deep historical origins in many disciplines. The tool spans numerous sectors and various disciplines, each with its own perspectives and evaluations of sustainability. Practitioner identities range from architects, engineers, and designers to academic researchers to corporate CEOs to weapons innovators $[35,45,56]$. In an emerging, under-analysed discipline with roots in widely varied contexts, the definitions and assumptions become of critical importance. BID that leads to sustainable results cannot be assumed, as is often the case in the popular media listed above. These types of articles have led many a corporate innovator to want to 'do biomimicry' with little realistic sense of the sustainability embedded in the outcomes. The 'doing' of biomimicry takes many forms and consequently, the analysis of BID in corporate settings spans a number of disciplines, making it an especially challenging research endeavour. It is understandable that practitioners of various disciplines lack comprehensive knowledge about the definitions and criteria of BID. Both the BID and business literature are vastly varied as related to the biophysical, social and economic aspects of sustainability.

\section{THE RELATIONSHIPS OF BUSINESS TO NATURE AND SOCIETY}

To understand the relationship of biomimicry to sustainability in corporate settings, it is equally critical to frame the relationships of the firm to sustainability. Without engaging in a full historical account, it is important to note that most management research till date has been inadequate in addressing sustainability as firm interactions with biophysical and social systems and instead has focused on environmental risks, use of natural resources and the environment as a repository for externalities and pollution [57,58]. When researching in management studies, one must not assume that a 'sustainable company' has considered the social or environmental impacts of their organization. With a few exceptions, '....Most management theorizing and research continues to proceed as if organizations lack biophysical foundations' [59]. This may be changing as corporate managers 
become more aware of resource scarcity, climate change and dependence on ecosystem services as some authors have highlighted [31,60,61].

Particularly helpful models in this shifting dialogue were contributed by Marcus, et al. Refer to Figure 1 in which they framed the relationships between business, nature and society with three changing trends. The first model, the 'Disparate View', can be traced back to the more traditional models of capitalism. In this view, the role of both Nature $(\mathrm{N})$ and Society $(\mathrm{S})$ is to serve and be subservient to the requirements of Business (B). It was assumed that the market would solve negative externalities in Nature and Society and the model served businesses well throughout the industrial revolution. The second model, the 'Intertwined View' emerged in the late 1980s and 1990s. This view has also been called the 'Triple Bottom Line' [22]. It gives equal weight to all three aspects-Business, Nature and Society—and targets the overlap of the three as the essence of sustainable development. The final framing is the 'Embedded View' which positions business as a subset of social systems which are, in turn, a subset of natural systems [60].

While this difference may seem subtle, it signifies a larger shift in thinking from one of dependence to one of interdependence with society and natural systems. This newfound position creates a platform for a dialogue between corporate agendas and societal sustainability agendas that acknowledges this interdependence. It also creates an entry point to begin to define exactly what the limits of natural systems are that may effect business activities, as several authors are attempting to do with planetary boundaries research [21,31,62-64].

In this view, it becomes apparent that merely emulating biological systems without a greater sense of interdependence is unlikely to bring human societies towards more sustainable ways of being. A necessary shift for BID to be a tool for sustainability in any sector is a transition towards a participatory model of humans in natural systems [35]. For BID to be helpful as a tool for SOI in corporate settings, corporate entities themselves need to have a strong sense of identity relating to sustainability and their role in biophysical systems.

\section{PRODUCTS, PROCESSES, ORGANIZATIONS AND SYSTEMS}

A challenging aspect of qualifying sustainability in BIDs relates to the many scales and sectors of application. The term 'biologically-inspired design' has been used as a catch-all phrase in this analysis because of its historical use, but the application of biological models to human innovation spans wellbeyond the world of design and into research as varied as swarm theory in computational applications, organizational ecology in management studies and even evolutionary epistemology [65-67]. Benyus identifies three levels of biomimicry-form, process and system-but corporate sustainability and innovation researchers name other levels of analysis for SOI and conventional innovations that speak to users beyond design disciplines and are better suited for a wider audience. These categories include: product, process, organization, system, position and paradigm $[8,9,12,68]$. Taking into account enormous variation in innovations and overlapping categories of definition, a blend of these approaches results in four categories to analyse sustainability-oriented BID: product-, process-, organization- and system-level innovations. Much of the research to date has been at the product- and process-levels although numerous examples of organization- and system-level BID exist in the grey and popular literature.

The concept of innovation systems positions any one innovation as part of a larger 'relational, interactive and cumulative process that occurs between producers and users of goods and services' [69]. Most recent progress in BID innovations also do not demonstrate relationships to innovations systems, in addition to the persistent gap of embeddedness in biophysical and social systems. Too frequently, the BIDs that are released in the popular and grey literature lack the contextual presence to have a significant impact on sustainable development because innovation systems are not considered holistically. 
The Disparate View

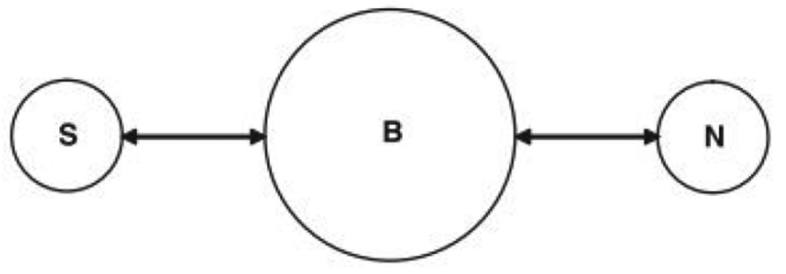

The Intertwined View

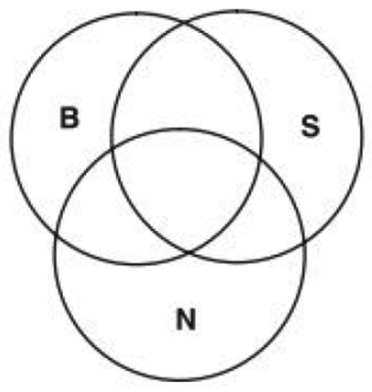

The Embedded View

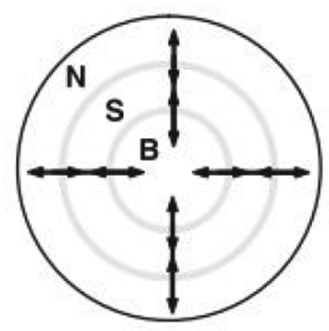

Figure 1: Changing views of the Business-Society-Nature relationships [60].

To help practitioners engage in sustainability-oriented BIDs, I propose the following nested model of Biologically-Inspired Innovations (BIIs) Refer to Figure 2. This model includes biomimicry and nature-inspired design as defined above, both in which sustainability is guided by natural systems, and expands to encompass broader levels of innovations not limited to traditional design disciplines. It excludes any BID not used for deepened sustainability and adaptability of the human species. For all practical purposes, the term biomimicry would be sufficient to describe this framework except that it is frequently associated with biomimetics, which often has no connection with sustainability.

Like the role of nature in the business-society-nature relationships above, this model positions systems as an underlying platform for all other types of innovations. Systems in this model include: socio-economic systems that span sectors; systems of production, consumption and waste; and ecosocio-techno-systems as described by Adams, et al. [8]. By definition, these types of innovations span beyond the unit of a corporate entity and include the multiple types of organizations as described next. Organizations are groups with legal and social identities such as corporations, governments, cooperatives, academic institutions and non-governmental organizations. Innovations at this level could also be considered management innovations. Processes are the ways by which products and 
services are produced and delivered. This can include manufacturing processes, organizational processes and others. Products are anything that a consumer would prescribe a value to coming from an organization including physical products, services and experiences. (These definitions are used for descriptive purposes and not based on a detailed analysis of terms, but rather to form a common language for communication across disciplines.)

The purpose of this model is three-fold. First, there does not currently exist an explanatory structure for BIIs that includes the organization and there are numerous examples of BIIs emerging in this space, particularly within management studies. Second, this slicing of the innovation space speaks to business professionals who may not otherwise engage with the language of design. And finally, Benyus's early framing does not acknowledge the embeddedness of each level emulation that is necessary to support corporate sustainability agendas. If BIIs are to contribute to sustainable development, the pursuit of these innovations must always be considered in the larger social and biophysical innovation systems. Through the lens of BII, the creation of a systems innovation can support organizations which design processes to create products, all inspired by and participating in biological systems. These tiers of innovation are closely interconnected and SOI is arguably not possible when viewed as separate categories.

These examples were chosen because they in some way address the biophysical and/or social aspects of sustainability, although some are more robust examples than others. Without clearly defined sustainability criteria, it is difficult to judge this aspect of the innovation. Also of note is the exclusion of numerous examples of organizational ecology and business ecosystem metaphors. While these examples are plentiful in the management and popular literature, they do not connect users to sustainability beyond that of the organization (e.g. [81]), and consequently, do little to further the thinking around BID and sustainability. That is not to say that this is a necessary exclusion, but rather that the current thinking in the business literature strongly reflects the older paradigm of business being separate from nature.

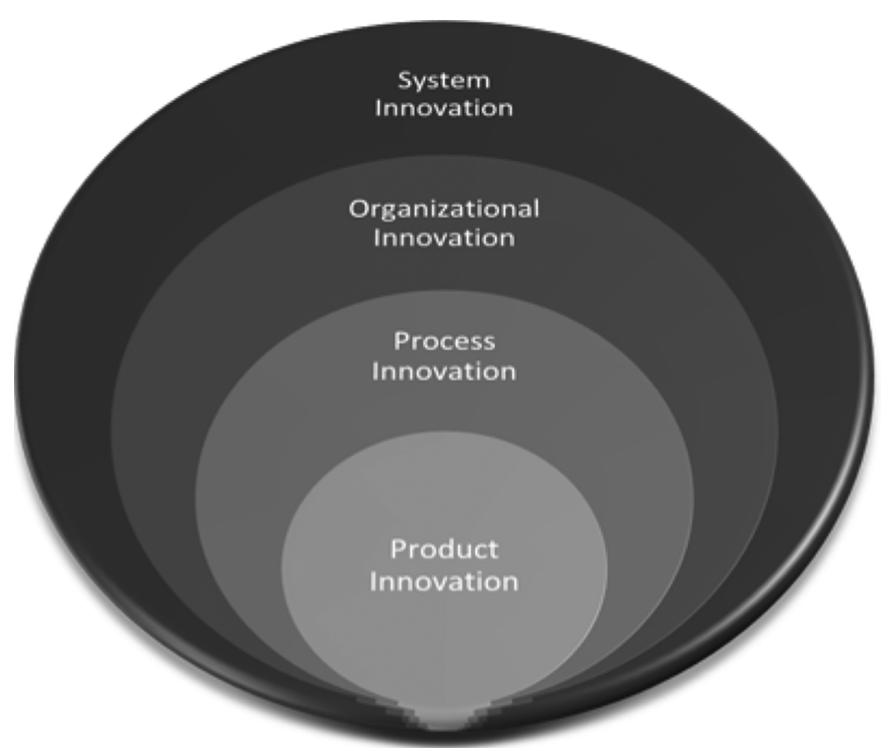

Figure 2: Embedded Model of Biologically-Inspired Innovations. 
Table 2: Examples of Biologically-Inspired Innovations

\begin{tabular}{|c|c|c|c|}
\hline & Example 1 & Example 2 & Example 3 \\
\hline \multicolumn{4}{|c|}{ System } \\
\hline Case Name & $\begin{array}{l}\text { Kalundborg Industrial } \\
\text { Symbiosis Park [70] }\end{array}$ & Desso [18] & Splosh [71] \\
\hline Innovation & $\begin{array}{l}\text { Industrial Ecology; } \\
\text { Production System }\end{array}$ & $\begin{array}{l}\text { Cradle-to-Cradle Life Cycle } \\
\text { Design [18] }\end{array}$ & Circular Economy [72] \\
\hline $\begin{array}{l}\text { Biological } \\
\text { Model }\end{array}$ & Waste $=$ Food & Ecosystems & Ecosystems \\
\hline \multicolumn{4}{|c|}{ Organization } \\
\hline Case Name & Interface [56] & $\begin{array}{l}\text { United States Green } \\
\text { Building Council [73] }\end{array}$ & $\begin{array}{l}\text { PAX Management } \\
\text { Strategy [74] }\end{array}$ \\
\hline Innovation & $\begin{array}{l}\text { Management } \\
\text { based on ecological } \\
\text { principles }\end{array}$ & $\begin{array}{l}\text { Support of a geographically } \\
\text { distributed } \\
\text { organization }\end{array}$ & $\begin{array}{l}\text { Employee selection as } \\
\text { part of an development of } \\
\text { an organizational system }\end{array}$ \\
\hline $\begin{array}{l}\text { Biological } \\
\text { Model }\end{array}$ & Ecological Principles & Several models & Diversity and Cooperation \\
\hline \multicolumn{4}{|c|}{ Process } \\
\hline Case Name & Dow Chemical [75] & Southwest Airlines [76] & HOK [77] \\
\hline Innovation & Green Chemistry & Optimized Cargo Routes & $\begin{array}{l}\text { Genius of the Biome; } \\
\text { Architecture }\end{array}$ \\
\hline $\begin{array}{l}\text { Biological } \\
\text { Model }\end{array}$ & Water-based Chemistry & Ant Colonies & $\begin{array}{l}\text { Temperate Broadleaf } \\
\text { Forest }\end{array}$ \\
\hline \multicolumn{4}{|c|}{ Product } \\
\hline & JR West [78] & Qualcomm [79] & Sto [80] \\
\hline Innovation & $\begin{array}{l}\text { High Speed } \\
\text { Train Design }\end{array}$ & Marisol $®$ Displays & Lotusan® Paint \\
\hline $\begin{array}{l}\text { Biological } \\
\text { Model }\end{array}$ & Kingfisher & Morpho Butterfly & Lotus Leaf \\
\hline
\end{tabular}

\section{CONCLUSIONS}

This paper has brought to light the various relationships and disconnects with BID and sustainable development at multiple levels. It has also provided a new conceptual model for corporate innovators to consider when utilizing BID strategies. Although there are numerous examples of metaphorical connections of BID to sustainability, a quantifiable and comparative measure has yet to be developed. With this kind of analytical research still nascent in management studies, it is no surprise that organizations 'doing biomimicry' assume that they are arriving at a more sustainable result simply by emulating natural systems. After all, it's difficult to argue with 3.8 billion years of evolutionary design. However, without a robust definition of sustainability and sustainable development that is 
easily accessible and can be operationalized by large companies, the actual implementation of those 3.8 billion years of evolutionary experience to the challenges of our time may be executed with less than sustainable results. There are no neutral applications of biology that exists without human interpretations laden with personal judgments, values and ethics [48].

This article attempts to create an operational model for large corporations to frame their use of BII for the greatest level of contribution to sustainable development. While it will not serve to address all uses of BID in all contexts, it may be a helpful addition to the ongoing dialogue regarding standardization of a biomimetic process currently underway at the International Organization for Standardization (www.iso.org). The self-contradiction of terms and similar issues surrounding the convoluted history should not be underestimated as the Technical Committee works though the process of certifying this adolescent discipline. It will not be a simple exercise of defining a biomimetic process, given with the wide breadth BID applications and the various users and stakeholders.

Without careful consideration, production of BIDs can be a pathway for perpetuating the many current unsustainable means of production and consumption under the guises of 'natural' systems [46]. The call for a high level of scrutiny of the claims of BID has been well documented, but to date, few attempts to bridge this knowledge gap have been made to deepen the connections between BID and SOI. We are still in the early days of this in this complex and necessary dialogue. Further development of Benyus's connection of innovation and evolution can shed light on a path forward. If we view technological and organizational evolution as part of the process of human evolution, sustainable development can be seen as a process of human evolution that includes the appropriate use of technology to support human participation in social and biophysical systems. Future research should include the connections of BII to the embedded view of corporate sustainability with platforms such as planetary boundaries and ecosystems services that emphasize human participation in biophysical systems.

\section{REFERENCES}

[1] Romei, F. Leonardo Da Vinci. The Oliver Press, Inc., 2008.

[2] Wiltgen, B., Vattam, S. \& Helms, M. Learning functional models of biological systems for biologically inspired design. 11th IEEE International Conference on Advanced Learning Technologies. 2011. doi: http://dx.doi.org/10.1109/icalt.2011.110

[3] De Pauw, I., Kandachar, P., Karana, E. \& Peck, D., Nature inspired design: Strategies towards sustainability. Knowledge Collaboration \& Learning for Sustainable Innovation ERSCP-EMSU Conference, Delft, Netherlands. pp. 1-21, 2010.

[4] Nelson, E., How Interface innovates with suppliers to create sustainability solutions. Glob Bus Organ Excell. Sept/Oct, pp. 22-30, 2009. doi: http://dx.doi.org/10.1002/joe.20285

[5] Chen, P. \& Nychka, J.A., Inspiration from nature - biomimetic materials workshop at the San Diego Zoo. J Mater., 63(6), pp. 19-21, 2011. doi: http://dx.doi.org/10.1007/s11837-011$\underline{0085-3}$

[6] Bonser, R.H.C., Patented biologically-inspired technological innovations: A twenty year view. J Bionic Eng., 3(1), pp. 39-41, 2006. doi: http://dx.doi.org/10.1016/s1672-6529(06)60005-x

[7] The Fermanian Business and Economic Institute. Global Biomimicry Efforts: An Economic Game Changer, pp. 1-43, 2010.

[8] Adams, R., Jeanrenaud, S., Bessant, J., Overy, P. \& Denyer, D., Innovating for sustainability: A systematic review of the body of knowledge, pp. 1-106, 2013.

[9] Klewitz, J. \& Hansen, E.G., Sustainability-oriented innovation of SMEs: A systematic review. J Clean Prod. July 65. pp. 57-75, 2014. doi: http://dx.doi.org/10.1016/j.jclepro.2013.07.017 
[10] Tidd, J., \& Bessant, J., Managing Innovation: Integrating Technological, Market and Organizational Change. John Wiley \& Sons, 2011.

[11] Adams, R., Bessant, J. \& Phelps, R., Innovation management measurement: A review. Int J Manag Rev., 8(1), pp. 21-47, 2006. doi: http://dx.doi.org/10.1111/j.1468-2370.2006.00119.x

[12] Benyus, J., Biomimicry: Innovation Inspired by Nature. HarperCollins, 1997. doi: http://dx.doi. org/10.2307/4450504

[13] Bar-Cohen, Y., Biomimetics - Using nature to inspire human innovation. Bioinspir Biomim., 1(1), pp. 1-12, 2006. doi: http://dx.doi.org/10.1088/1748-3182/1/1/p01

[14] Goel, A.K., McAdams, D.A. \& Stone, R.B., Biologically Inspired Design: Computational Methods and Tools, 2014. doi: http://dx.doi.org/10.1007/978-1-4471-5248-4

[15] Fish, F.E. \& Beneski, J.T., Evolution and bio-inspired design: natural limitations. Eds. Goel, A.K., McAdams, D.A. \& Stone, R.B. Biologically Inspired Design. London: Springer London. pp. 287-312, 2014. doi: http://dx.doi.org/10.1007/978-1-4471-5248-4 12

[16] Holden, G., Looking to nature to catalyze energy R\&D. Res Manag., Jul-Aug, pp. 7-8, 2012.

[17] Tàbara, J.D. \& Chabay, I., Coupling human information and knowledge systems with socialecological systems change: Reframing research, education, and policy for sustainability. Environ Sci Policy. Apr. 28, pp. 71-81, 2013. doi: http://dx.doi.org/10.1016/j.envsci.2012.11.005

[18] Braungart, M. \& McDonough, W., Cradle to Cradle: Remaking the Way We Make Things. Random House, 2002. doi: http://dx.doi.org/10.4337/9781847203052.00011

[19] Heinberg, R., Peak Everything. Clairview Books, 2007.

[20] Meadows, D.H., Meadows, D.I., Randers, J. \& Behrens III, W.W., The Limits to Growth: A Report to The Club of Rome. pp. 1-9, 1972. doi: http://dx.doi.org/10.1349/ddlp.1

[21] Rockström, J., Steffen, W., Noone, K., Persson, Å., Chapin, F.S. \& Lambin, E.F., et al., A safe operating space for humanity. Nature. 461(Sept), pp. 472-5, 2009. doi: http://dx.doi. org/10.1038/461472a

[22] Elkington, J., Cannibals With Forks: The Triple Bottom Line of 21st Century Business. Capstone Publishing Ltd, Oxford, 1997. doi: http://dx.doi.org/10.5860/choice.36-3997

[23] Hall, J. \& Wagner, M., Integrating sustainability into firms' processes: Performance effects and the moderating role of business models and innovation. Bus Strateg Environ., 21(3), pp. 183-96, 2012. doi: http://dx.doi.org/10.1002/bse.728

[24] Switzer, J. \& Ehrenfeld J.R., Independent environmental auditors: What does ISO 14001 registration really mean? Environ Qual Manag. Autumn. pp. 17-33, 1999.

[25] Perego, P. \& Kolk, A., Multinationals' accountability on sustainability: The evolution of thirdparty assurance of sustainability reports. J Bus Ethics., 110(2). pp. 173-190, 2012. doi: http:// dx.doi.org/10.1007/s10551-012-1420-5

[26] Böhringer, C. \& Jochem, P.E.P., Measuring the immeasurable - A survey of sustainability indices. Ecol Econ., 63(1). pp. 1-8, 2007. doi: http://dx.doi.org/10.1016/j.ecolecon.2007.03.008

[27] Kemp, R., Measuring eco-innovation. United Nations Univ Res Br., (1), pp. 1-8, 2008.

[28] Van Zeijl-Rozema, A., Ferraguto, L., \& Caratti, P., Comparing region-specific sustainability assessments through indicator systems: Feasible or not? Ecol Econ., 70(3), pp. 475-486, 2011. doi: http://dx.doi.org/10.1016/j.ecolecon.2010.09.025

[29] Wolff, F. \& Schönherr, N., The impact evaluation of sustainable consumption policy instruments. J Consum Policy., 34(1), pp. 43-66, 2011. doi: http://dx.doi.org/10.1007/s10603-010$\underline{9152-3}$

[30] Pogutz, S. \& Winn, M., Organizational ecosystem embeddedness and its implications for sustainable fit strategies. Research Seminar at Universita Bocconi, 2011. 
[31] Whiteman, G., Walker, B. \& Perego, P., Planetary boundaries: Ecological foundations for corporate sustainability. J Manag Stud., 50(2), pp. 307-36, 2013. doi: http://dx.doi.org/10.1111/ j.1467-6486.2012.01073.x

[32] Nidumolu, R., Prahalad, C.K. \& Rangaswami, M.R., Why sustainability is now the key driver of innovation. Harv Bus Rev., Sep. pp. 1-10, 2009. doi: http://dx.doi.org/10.1109/ emr.2013.6601104

[33] Kallio, T.J. \& Nordberg, P., The evolution of organizations and natural environment discourse: Some critical remarks. Organ Environ., 19(4), pp. 439-457, 2006. doi: http://dx.doi. org/10.1177/1086026606294955

[34] Bejan, A. \& Lorente, S., Constructal law of design and evolution: Physics, biology, technology, and society. J Appl Phys., 2013. doi: http://dx.doi.org/10.1063/1.4798429

[35] Wahl, D.C., Bionics vs. biomimicry: From control of nature to sustainable participation in nature. Design in Nature III: Comparing Design in Nature with Science and Engineering. WIT Press: Southampton, UK. pp. 289-98, 2006. doi: http://dx.doi.org/10.2495/dn060281

[36] Marshall, A. \& Lozeva, S., Questioning the theory and practice of biomimicry. Int J Des Nat Ecodynamics, 4(1), pp. 1-10, 2009. doi: http://dx.doi.org/10.2495/dne-v4-n1-1-10

[37] Iouguina, A., Dawson, J.W., Hallgrimsson, B. \& Smart, G., biologically informed disciplines : a comparative analysis of terminology within the fields of bionics, biomimetics, biomimicry and bio-inspiration, among others. Pending Publication in Des Nat VII, 2014.

[38] Knippers, J. \& Speck, T., Design and construction principles in nature and architecture. Bioinspir Biomim., 7(1), pp. 1-10, 2012. doi: http://dx.doi.org/10.1088/1748-3182/7/1/015002

[39] McHarg, IL., Design With Nature. Natural History Press., 1969.

[40] Lange-Merrill, C., Biomimicry of the Dooxygen Active Site in the Cooper Proteins Hemocyanin and Cytocrhrome Oxidase. Doctoral Thesis, pp. 1-204, 1982.

[41] Marshall, A., The theory and practice of ecomimicry. Sustain Gondwana. Aug(3), pp. 1-32, 2007.

[42] Vincent, J.F., Bogatyreva, O.V., Bogatyrev, N.R., Bowyer, A. \& Pahl, A.K., Biomimetics: Its practice and theory. J R Soc Interface, 3(9), pp. 471-82, 2006. doi: http://dx.doi.org/10.1098/ rsif.2006.0127

[43] Harkness, J.M., In appreciation: A lifetime of connections: Otto Herbert Schmitt, 1913-1998. Phys Perspect., 4(4), pp. 456-490, 2002. doi: http://dx.doi.org/10.1007/s000160200005

[44] Biomimicry 3.8. Online: http://biomimicry.net/. 2014. doi: http://dx.doi.org/10.1016/b978-0$\underline{12-415995-2.00019-2}$

[45] Johnson, E.R., Reanimating bios: Biomimetic science and the empire. Doctoral Thesis. pp. 1-222, 2011.

[46] Mathews, F., Towards a deeper philosophy of biomimicry. Organ Environ., 24(4), pp. 364-87, 2011. doi: http://dx.doi.org/10.1177/1086026611425689

[47] Lepora, N.F., Verschure, P. \& Prescott T.J., The state of the art in biomimetics. Bioinspir Biomim. 8(1), pp. 1-11, 2013. doi: http://dx.doi.org/10.1088/1748-3182/8/1/013001

[48] Kaye, H.L., The Social Meaning of Modern Biology. Transaction Publishers, 1997.

[49] Mueller, T., Biomimetics. National Geographic Magazine. Online: http://ngm.nationalgeographic.com/2008/04/biomimetics/tom-mueller-text, 2013.

[50] Hutchins, G., Biomimicry: Looking to nature to solve human problems. Guardian Sustainable Business Blog. 2013. Online: http://www.theguardian.com/sustainable-business/blog/biomimcry-nature-human-problems-sustainability. 
[51] Hennighausen, A. \& Roston, E., 14 smart inventions inspired by nature. Bloomberg: Sustainability. Online: http://www.bloomberg.com/slideshow/2013-08-18/14-smart-inventions-inspired-by-nature-biomimicry.html, 2013.

[52] Ungereleider, N. Mims, C., Clendaniel, M. \& Parr, S., Biomimicry. Fast Company. Online: http://www.fastcompany.com/section/biomimicry, 2013.

[53] Mason, S., Ingredient innovation: Inspired by nature. Ingredients: Eco Trends., Mar. pp. 44-47, 2012.

[54] Jacobsen, N.B., Industrial Symbiosis in Kalundborg, Denmark. J Ind Ecol., 1, pp. 239-55, 2006. doi: http://dx.doi.org/10.1162/108819806775545411

[55] Volstad, N.L. \& Boks, C., On the use of biomimicry as a useful tool for the industrial designer. Sustain Dev., 20(3), pp. 189-199, 2012. doi: http://dx.doi.org/10.1002/sd.1535

[56] Anderson, R., Confessions of a Radical Industrialist: How Interface Proved That You Can Build a Successful Business Without Destroying the Planet. Random House, 2010.

[57] Linnenluecke, M.K. \& Griffiths, A., Firms and sustainability: Mapping the intellectual origins and structure of the corporate sustainability field. Glob Environ Chang., 23(1), pp. 382-391, 2012. doi: http://dx.doi.org/10.1016/j.gloenvcha.2012.07.007

[58] Hart, S.L., Milstein, M.B. \& Caggiano, J., Creating sustainable value. Acad Manag Exec., 17(2), pp. 56-69, 2013.

[59] Gladwin, T.N., Kennelly, J.I., Krause, T. \& Hugo, V., Shifting paradigms for sustainable development: Implications for management theory and research. Acad Manag Rev., 20(4), pp. 874-907, 1995. doi: http://dx.doi.org/10.5465/amr.1995.9512280024

[60] Marcus, J., Kurucz, E.C. \& Colbert B.A., Conceptions of the Business-Society-Nature interface: Implications for management scholarship. Bus Soc., 49(3), pp. 402-438, 2010. doi: http:// dx.doi.org/10.1177/0007650310368827

[61] Winn, M.I. \& Pogutz, S., Business, ecosystems, and biodiversity: New horizons for management research. Organ Environ., 26(2), pp. 203-229, 2013. doi: http://dx.doi.org/10.1177/ 1086026613490173

[62] Biermann, F., Planetary boundaries and earth system governance: Exploring the links. Ecol Econ. 81, pp. 4-9. 2012. doi: http://dx.doi.org/10.1016/j.ecolecon.2012.02.016

[63] Leach, M., Raworth, K. \& Rockström, J. Between social and planetary boundaries: Navigating pathways in the safe and just space for humanity. World Social Science Report, pp. 84-89, 2013. doi: http://dx.doi.org/10.1787/9789264203419-10-en

[64] Muys, B., Sustainable development within planetary boundaries : A functional revision of the definition based on the thermodynamics of complex social-ecological systems. Chal Sust., 1(1) pp. 41-52, 2013. doi: http://dx.doi.org/10.12924/cis2013.01010041

[65] Engelbrecht, A.P., Fundamentals of Computational Swarm Intelligence, 2005. doi: http://dx .doi.org/10.1109/sis.2005.1501612

[66] Singh, J.V. \& Lumsden, C.J., Theory and research in organizational ecology. Annu Rev Sociol. 16, pp. 161-95, 1990. doi: http://dx.doi.org/10.1146/annurev.so.16.080190.001113

[67] Hahlweg, K. \& Hoooker, C.A., Issues in Evolutionary Epistemology: Contemporary Engagements Between Analytic and Continental Thought. SUNY Press, 1989.

[68] Bessant, J. \& Tidd, J., Innovation and Entrepreneurship. John Wiley \& Sons, 2007. doi: http:// dx.doi.org/10.1108/00251740910946778

[69] Altenburg, T. \& Pegels, A., Sustainability-oriented innovation systems - managing the green transformation. Innov Dev., 2(1) pp. 5-22, 2012. doi: http://dx.doi.org/10.1080/215793 $\underline{0 x .2012 .664037}$ 
[70] Ehrenfeld, J. \& Gertler, N., Industrial ecology in practice: The evolution of interdependence at Kalundborg. J Ind Ecol., 1(1), pp. 67-79, 1997. doi: http://dx.doi.org/10.1162/jiec.1997.1.1.67

[71] Ellen MacArthur Foundation. Case Studies: Splosh. Online: http://www.ellenmacarthurfoundation.org/case_studies/splosh.

[72] Ellen Macarthur Foundation. Towards the Circular Economy, 1, p. 96, 2013.

[73] Walker A., Biomimicry Challenge: IDEO Taps Octopi and Flamingos to Reorganize the USGBC. Fast Company: Business + Innovation. Online: http://www.fastcompany.com/1643489/ biomimicry-challenge-ideo-taps-octopi-and-flamingos-reorganize-usgbc, 2013.

[74] Harman, J., The Shark's Paintbrush: Biomimicry and How Nature is Inspiring Innovation. Nicholas Brealey Publishing, 2013.

[75] Nameroff, T.J., Garant, R.J. \& Albert, M.B., Adoption of green chemistry: an analysis based on US patents. Res Policy, 33(6-7), pp. 959-74, 2004. doi: http://dx.doi.org/10.1016/j.respol.2004.03.001

[76] Bonabeau, E. \& Meyer, C., Swarm Intelligence: A Whole New Way to Think About Business. Harv Bus Rev. May, pp. 106-14, 2001.

[77] HOK \& Biomimicry 3.8. Genius of the Biome Report. p. 178. Online: http://biomimicry.net/ consulting/genius-of-biome-report/, 2013.

[78] Kim, S-J \& Lee, J-H., How biomimetic approach enlarges morphological solution space in a streamlined high-speed train design? Proceedings of the 16th SIGRADI Conference. pp. 538-42, 2012.

[79] Kumar, R., Smith, S., McNeilan, J., Keeton, M., Sanders, J., Talamo, A., et al., Butterfly wing-inspired nanotechnology. The Nanobiotechnology Handbook, CRC Press, p. 692, 2012. doi: http://dx.doi.org/10.1201/b12935-11

[80] Bixler, G.D., Theiss, A., Bhushan, B. \& Lee, S.C., Anti-fouling properties of microstructured surfaces bio-inspired by rice leaves and butterfly wings. J Colloid Interface Sci., 419. pp. 114-33, 2014. doi: http://dx.doi.org/10.1016/j.jcis.2013.12.019

[81] Okey, T.A., Strategy as ecology: Critique of the Keystone Advantage. Harv Bus Rev. Sep. p. 132, 2004. 